\title{
Mineralogy and Maximum Phosphorus Adsorption Capacity in Soybean Development
}

\author{
Reginaldo de Oliveira ${ }^{1}$, Laércio Santos Silva ${ }^{1}$, Naiara Fernanda de Souza ${ }^{2}$, Marizane Pietroski ${ }^{2}$, Gustavo Caione ${ }^{2}$, \\ Getulio de Freitas Seben Júnior ${ }^{2}$, Guilherme Ferreira Ferbonink ${ }^{2}$, Romário Pimenta Gomes ${ }^{3}$, José Marques Júnior ${ }^{1}$, \\ Gustavo André de Araújo Santos ${ }^{1} \&$ Milton César Costa Campos $^{4}$ \\ ${ }^{1}$ Universidade Estadual Paulista, Brazil \\ ${ }^{2}$ Universidade do Estado de Mato Grosso, Brazil \\ ${ }^{3}$ Universidade Estadual Jaboticabal, Brazil \\ ${ }^{4}$ Universidade Federal do Amazonas, Brazil \\ Correspondece: Laércio Santos Silva, Universidade Estadual Paulista, Brazil. E-mail: \\ laerciosantos18@gmail.com
}

Received: March 28, 2018

Accepted: May 5, $2018 \quad$ Online Published: June 15, 2018

doi:10.5539/jas.v10n7p242

URL: https://doi.org/10.5539/jas.v10n7p242

\begin{abstract}
The low natural fertility of tropical soils and the mineralogy almost dominated by iron and aluminum oxides limit the availability of phosphorus $(\mathrm{P})$ to the plants, causing negative impacts on soybean yield. Objective was to evaluate the effect of phosphate fertilization on soils with different maximum phosphorus adsorption capacities (PAC) in soybean development. The experiment was carried out under greenhouse conditions, using Red-yellow Latosol (RYL) and a Typic Hapludalf (TH) soil as substrate. The analyses were performed by a completely randomized experimental design in a $5 \times 2$ factorial arrangement with three replications. The treatments consisted of 5 doses of $\mathrm{P}$ applied, corresponding to $0,1,6,12$, and $24 \%$ of PAC of each soil. In the soil, the mineralogy of the clay fraction (hematite, goethite, gibbsite and kaolinite) and crystallographic attributes were characterized. In the plant, we evaluated growth and pod production. The PAC of the soils ranged from 220 to $650 \mathrm{mg} \mathrm{dm}^{-3}$ with higher value in the RYL associated to clayey oxidic mineralogy and texture in relation to the TH of kaolinite origin and sandy texture, where the higher energy of adsorption observed was to TH. Phosphorus application from 16 to $21 \%$ of PAC, independently of the soil, promotes the same pattern of response with improvements in soybean development evidenced by increases in P content in plant tissue, plant height, root volume and aerial dry mass.
\end{abstract}

Keywords: grain production, oleaginous, langmuir isotherm

\section{Introduction}

Soybean is one of the most economically important oilseeds. It is growth in large areas, previously cultivated with degraded pastures (Feba, Moro, \& Guerra, 2017). Due to its soils are naturally low in fertility, fertilization adjustments are necessary to establish a productive system (Caires, Sharr, Joris, Haliski, \& Bini, 2017). In this scenario the Mato Grosso State Cerrado (Savanna) stands out, which holds the Brazilian largest soybean production area. However, the advanced weathering of cerrado soils limits soybean productivity, mainly due to the lack of phosphorus (P) (Souza \& Lobato, 2002; Roy et al., 2017), since much of this nutrient is strongly retained in the oxidic mineralogy of these soils (Guedes, Fernandes, Souza, \& Silva, 2015; Fink, Inda, Tiecher, \& Barrón, 2016).

In tropical soils, clay minerals govern the sorption and adsorption mechanism of $\mathrm{P}$, both supplying this nutrient to the plant and competing for P applied in phosphate fertilizers (Rolim Neto, Schaefer, Costa, Corrêa, Fernandes Filho, \& Ibraimo, 2004). Several investigations have shown that goethite $(\mathrm{Gt}=\alpha-\mathrm{FeOOH})$ and gibbsite $(\mathrm{Gb}=$ $\left.\gamma-\mathrm{Al}(\mathrm{OH})_{3}\right)$ rich soils provide higher P-fixing power than hematite-governed soils $\left(\mathrm{Hm}=\alpha-\mathrm{Fe}_{2} \mathrm{O}_{3}\right)$ and, secondarily, kaolinite (Kt) (Broggi, Oliveira, F. J. Freire, M. B. G. S. Freire, \& Nascimento, 2011; Barbieri et al., 2014). In a pioneer study developed in the Brazilian Cerrado, Novais and Smyth (1999) found in clayey Latosols more than $2 \mathrm{mg} \mathrm{cm}^{-3}$ of adsorbed $\mathrm{P}$, which is equivalent to $4000 \mathrm{~kg} \mathrm{ha}^{-1}$ of $\mathrm{P}$, that is, $9.200 \mathrm{~kg} \mathrm{ha}^{-1}$ of $\mathrm{P}_{2} \mathrm{O}_{5}$, 
incorporated at 0-20 cm. In turn, Paula, Martins, Farias, and Siqueira (2016) found in $1 \mathrm{~kg}$ of soil approximately $20 \mathrm{~g}$ of goethite and 30 to $60 \mathrm{~g}$ of hematite in a Typic Haplortox, with about 401 to $552 \mathrm{mg}$ of adsorbed P.

The kaolinite soils secondary effect on the P adsorption potential, according to Gomes (2017) is due to its low specific surface area, limited only to external surfaces. In fact, unlike iron oxides, kaolinite presents low load and specific surface area, limiting itself only to external surfaces (Melo \& Wypych, 2009), conferring low fixation of anionic groups such as phosphate. Besides the type of mineral, the crystallographic attributes such as specific surface (SS), isomorphic substitution (IS), and mean diameter of the crystal (MDC) play an important role in adsorption of P (Fink et al., 2016). Thus, the high SS area, associated with low crystallinity minerals, allows higher retention of $\mathrm{P}$, due to the higher density of $\mathrm{OH}$-charges exposed on the surface.

One of the bottlenecks in tropical agriculture is the discernment of how much of phosphate fertilizers must be used to ensure good soybean yields. This deadlock occurs due to the mineralogical knowledge low utilization of the cultivated soils, and therefore, the decision on the total fertilizer to be used, is still based only on the crop requirement, expected productivity, and soil clay content (Caires et al., 2017). Because of this, the results are many times unsatisfactory, because this fertilization do not meet the requirements of the crop, since much of the P applied can be complexed or fixed by the soil constituents (Pavinato, Merlin, \& Rosolem, 2009; Pinto, Souza, Paulino, Curi, \& Carneiro, 2013). For example, in a Typic Haplorthox, Valadão Júnior, Bergamin, Reis Venturoso, Schlindwein, and Otomar Caron (2008), and Araújo, Sampaio, and De Medeiros (2008), based on the expected soybean yield, found the maximum plant height at doses $140 \mathrm{~kg} \mathrm{ha}^{-1}$ of $\mathrm{P}_{2} \mathrm{O}_{5}$ and $192.07 \mathrm{~kg} \mathrm{ha}^{-1}$ of $\mathrm{P}_{2} \mathrm{O}_{5}$, respectively. These differences are probably attributed to soil mineralogy, reinforcing the necessity of better understand the soil mineralogy to estimate PAC and, consequently, to use strategic management to a better planning of phosphate fertilizations in the soil (Peluco, Marques Júnior, Siqueira, Pereira, Barbosa, \& Teixeira, 2015).

Mathematical models have been used to describe $\mathrm{P}$ adsorption mechanism at a $\mathrm{P}$ increasing concentration in the equilibrium solution or varying the time-soil P contact (Novais \& Smyth, 1999). Among the models, there is a preference for the Langmuir isotherm, because it allows to obtain the maximum soil phosphorus adsorption capacity (PAC) and the constant "k", related to the energy of this element binding to the soil (Novais \& Smyth, 1999). As it turns, the PAC is strongly associated with the clay content and the type of mineral present in the soil (Rolim Neto et al., 2004; Simões Neto et al., 2009; Corrêa, Nascimento, \& Tavares, 2011).

The information obtained by the isotherms shows soils with greater or lesser capacity to adsorb $\mathrm{P}$ and, consequently, it helps in a more efficient planning of phosphate fertilizations, allowing to minimize costs and also possible impacts to the growth environment (Gomes, 2017). In Cerrado, there is a lack of study that considers the potential of soybean exploration related to the mineralogical aspects of the soil. Aiming to fill this gap, this study proposes to evaluate the effect of phosphate fertilization on soils with different maximum phosphorus adsorption capacities (PAC) in soybean development.

\section{Material and Methods}

\subsection{Experimental Procedure}

The experiment was carried out in a greenhouse belonging to the State University of Mato Grosso, Alta Floresta, MT, Brazil. The soil samples used in the cultivation were collected at $0-20 \mathrm{~cm}$ of Red-Yellow Distrophic Latosol (RYL) and Typic Hapludalf (TH) (Embrapa, 2013).

After sampling, soil was limed with dolomitic limestone $(30 \% \mathrm{CaO}$ and $21.1 \% \mathrm{MgO})$ with $100 \%$ total neutralization power (TNP), estimating to raise the soybean soil base saturation to the $60 \%$, following the fertilization recommendations to Brazilian Cerrado (Souza \& Lobato, 2002). The soil remained incubated at field capacity moisture for 30 days. After this time, a basic micronutrient fertilization (boron and zinc) was done, using the boric acid and zinc sulfate sources at $0.5 \mathrm{mg} \mathrm{dm}^{-3}$ of B and $1 \mathrm{mg} \mathrm{dm}^{-3}$ of $\mathrm{Zn}$, respectively. In addition, a potassium fertilization was applied incorporating to the soil $150 \mathrm{mg} \mathrm{dm}^{-3}$ of $\mathrm{K}$ (Malavolta, 1981), using as source potassium chloride.

\subsection{Statistical Design}

We used a completely randomized statistical design, in a $5 \times 2$ factorial arrangement. The treatments were 5 doses of $\mathrm{P}$ applied, corresponding to $0,1,6,12$ and $24 \%$ of PAC in 2 soils, RLY and TH. The doses of P applied, resemble those used by (Simões Neto et al., 2015). To reach the desired percentage of PAC in each soil, it was necessary to apply: $0,15,90,180$, and $360 \mathrm{mg} \mathrm{dm}^{-3}$ of $\mathrm{P}_{2} \mathrm{O}_{5}$ in RYL, and $0,5,30,60$, and $120 \mathrm{mg} \mathrm{dm}^{-3}$ of $\mathrm{P}_{2} \mathrm{O}_{5}$ in $\mathrm{TH}$, respectively. As a source of $\mathrm{P}$, the TOP $\mathrm{PHOS}^{\circledR}$ (Timac Agro Brasil) was used with $28 \%$ of $\mathrm{P}_{2} \mathrm{O}_{5}$. Each 
experimental plot was composed of a $6 \mathrm{dm}^{3}$ polyethylene vessel containing two M 8372 IPRO variety soybean plants (Glycine max).

The M 8372 IPRO soybean seeds were previously inoculated with nitrogen fixing bacteria Bradyrhizobium japonicum before planting, at $0.5 \mathrm{~mL}$ p.w. $\mathrm{kg}^{-1}$ of seed-SEMIA 5079 and 5080 strains, inoculant Nitro 1000 soybean ${ }^{\circledR}\left(5.0 \times 10^{9}\right.$ viable cells per $\left.\mathrm{ml}\right)$, being sowed 4 seeds per pot. During the experimental period irrigation was carried out keeping the moisture content close to $60 \%$ of the soil water retention capacity by monitoring the weight difference (soil weight with $60 \%$ and weight before irrigation).

The soybean plants were grown until full pod formation, at the R4 development stage (Fehr \& Caviness, 1977), which occurred at 91 days, being at this time harvested. We evaluated, according procedures suggested by Bouma, Nielson, and Koutstaal (2000), the number of pods per plant, plant height (with a ruler-cm), and the root volume (with a graduated cylinder). The results were expressed in $\mathrm{cm}^{3}$.

\subsection{Soil Analysis}

In order to characterize the soils samples they were collected in each $6 \mathrm{dm}^{3}$ vessel, then air dried and passed through a $2 \mathrm{~mm}$ diameter sieve. According to the Table 1, in the soils were found the chemical attributes where, $\mathrm{pH}$ (water), $\mathrm{K}^{+}, \mathrm{Ca}^{2+}, \mathrm{Mg}^{2+}$, $\mathrm{P}$, potential acidity $\left(\mathrm{H}^{+}+\mathrm{Al}^{3+}\right)$, $\mathrm{T}$ and $\mathrm{V} \%$, and granulometric attributes as: sand, silt and clay, all performed according to the methodologies described for Embrapa (2011).

Table 1. Chemical and granulometric soil attributes prior to the fertilization

\begin{tabular}{lll}
\hline \multirow{2}{*}{ Atributes } & \multicolumn{2}{c}{ Solos } \\
\cline { 2 - 3 } & RYL & TH \\
\hline $\mathrm{pH}\left(\mathrm{H}_{2} \mathrm{O}\right)$ & 5.9 & 5.0 \\
$\mathrm{Ca}\left(\mathrm{cmol}_{\mathrm{c}} \mathrm{dm}^{-3}\right)$ & 2.58 & 1.40 \\
$\mathrm{Mg}\left(\mathrm{cmol}_{\mathrm{c}} \mathrm{dm}^{-3}\right)$ & 1.09 & 0.57 \\
$\mathrm{~K}\left(\mathrm{mg} \mathrm{dm}^{-3}\right)$ & 193.1 & 35.9 \\
$\mathrm{P}_{\text {mehlich-1 }}\left(\mathrm{mg} \mathrm{dm}^{-3}\right)$ & 8.7 & 4.0 \\
$\mathrm{H}+\mathrm{Al}\left(\mathrm{cmol}_{\mathrm{c}} \mathrm{dm}^{-3}\right)$ & 4.24 & 3.29 \\
$\mathrm{~T}\left(\mathrm{cmol}_{\mathrm{c}} \mathrm{dm}^{-3}\right)^{*}$ & 8.4 & 5.4 \\
$\mathrm{~V}(\%)^{* *}$ & 49.6 & 38.5 \\
$\mathrm{Clay}(\%)$ & 64.4 & 22.9 \\
Silt $(\%)$ & 8.2 & 8.1 \\
Sand $(\%)$ & 31.4 & 69 \\
\hline
\end{tabular}

Note. $*$ Potential cation exchange capacity; ** Base saturation.

We characterized the main minerals of the clay fraction, i.e., hematite $(\mathrm{Hm})$, goethite $(\mathrm{Gt})$, kaolinite $(\mathrm{Ct})$ and gibbsite $(\mathrm{Gb})$ by X-ray diffraction through the powder method after iron oxides concentration, according to Norrish and Taylor (1961) and the clay fraction deferrification by the method of Mehra and Jackson (1960). The samples were diffracted with a scanning speed of $1^{\circ} 20 \mathrm{~min}^{-1}$ using Mini-Flex Rigaku II (20mA, 30kV), equipped with $\mathrm{Cu} \mathrm{K} \alpha$ radiation. The $\mathrm{Hm} /(\mathrm{Gt}+\mathrm{Hm})$ ratio was estimated by comparing the peak areas obtained from $\mathrm{Hm} /(\mathrm{Gt}+\mathrm{Hm})$ XRD with the ratio ratios obtained from standard Gt-Hm mixtures. The percentages of $\mathrm{Hm}$ and $\mathrm{Gt}$ were calculated by allocating the difference between Fed and Feo to these oxides. The $\mathrm{Ct} /(\mathrm{Ct}+\mathrm{Gb})$ ratio was calculated by the $\mathrm{Gb}(002)$ and $\mathrm{Ct}(001)$ peak reflection areas.

The iron-aluminum isomorphic substitution content calculation in Gt was obtained by the Schulze equation (1984): $\mathrm{Al}\left(\mathrm{mol} \mathrm{mol}^{-1}\right)=17.30-5.72 \times \mathrm{c}_{0}$. We calculated the iron-aluminum isomorphic substitution content in Hm using the Schwertmann and Taylor (1989) equation: $\mathrm{Al}\left(\mathrm{mol} \mathrm{mol}^{-1}\right)=31.09-6.17 \times \mathrm{a}_{0}$. The specific surface area (SSA) of Gt was estimated according to Schulze and Schwertmann (1984): SSA $(\mathrm{Gt})=(1049 / \mathrm{DMC} 100)-5$ $\left(\mathrm{m}^{2} \mathrm{~g}^{-1}\right)$, where, DMC100 = DMC $(110) \times 0.42 \mathrm{~nm}($ Kämpf, 1981). The SSA to Hm was calculated according to (Schwertmann \& Kämpf, 1985) by the formula: SSA $(\mathrm{Hm})=2 \times(\mathrm{r}+\mathrm{h}) \times \mathrm{d}\left(\mathrm{m}^{2} \mathrm{~g}^{-1}\right)$. The mean crystal diameter (MCD) of Hm and Gt was calculated from the Half Height Width (HHW) and the minerals reflection position using the Scherrer equation (Schulze, 1984).

\subsection{Determination of Maximum Phosphorus Adsorption Capacity (PAC)}

In order to determine the potential of phosphorus adsorption in each soil to determine the doses used in each soil the maximum phosphorus adsorption capacity (PAC) was determined in the evaluated soils. For this analysis, 5 
$\mathrm{cm}^{3}$ of soil was added in a $125 \mathrm{ml}$ Erlenmeyer flask together to $50 \mathrm{ml}$ of $0.01 \mathrm{~mol} \mathrm{~L}^{-1} \mathrm{CaCl}_{2}$ solution with the following P concentrations $\left(0,2,4,10,20,40,60,80,100\right.$, and $120 \mathrm{mg} \mathrm{L}^{-1}$ of $\left.\mathrm{P}\right)$ as $\mathrm{KH}_{2} \mathrm{PO}_{4}$. Then the samples were kept in a horizontal shaker for 4 hours, and after that the supernatant was collected to determine $\mathrm{P}$ by spectrophotometry at $660 \mathrm{~nm}$ range (Embrapa, 2009).

After the readings, $\mathrm{P}$ adsorption was estimated by the difference between the amount of $\mathrm{P}$ found in the equilibrium solution and the amount of $\mathrm{P}$ added. With the results we constructed the adsorption isotherms, with data of $\mathrm{P}$ adsorbed plotted on the ordinates axis and the predetermined concentrations in the equilibrium solution on the abscissa axis.

The Langmuir equation in its hyperbolic form is expressed by: $\mathrm{x} / \mathrm{m}=(\mathrm{abC}) /(1+\mathrm{aC})$. In order to estimate the constants $a$ and $b$, the hyperbolic Langmuir equation was linearized: $C /(x / m)=1 /(a b)+(1 / b) C$, where, $x / m$ is the amount of $\mathrm{P}$ adsorbed by the soil, in $\mathrm{mg} \mathrm{P}(\mathrm{x}) / \mathrm{cm}^{3}$ of soil $(\mathrm{m})$; b; soil PAC, ( $\mathrm{mg} \mathrm{cm}^{-3}$ of $\mathrm{P}$ in soil); C: $\mathrm{P}$ concentration in the equilibrium solution (supernatant) expressed in $\mathrm{mg} \mathrm{L}^{-1}$; a: constant related to soil $\mathrm{P}$ adsorption energy, expressed in $\mathrm{mg} \mathrm{L}^{-1}$ (Olsen \& Watanabe, 1957).

\subsection{Plant Analysis}

We collected the aerial part of the plant (leaves, stems, pods) and roots, which were dried at $65^{\circ} \mathrm{C}$ in a forced air circulation oven, until reaching constant weight, thus obtaining the weight of dry mass. The dry plant material was ground and used for the quantification of $\mathrm{P}$ contents in the plant tissue, according to the methodology proposed by (Embrapa, 2009).

\subsection{Statistical Analysis}

The results were submitted to analysis of variance (F test) and when significant, the Tukey test was performed at $5 \%$ probability for the soil and polynomial regression for doses (PAC). Each one of the model component coefficients were tested by choosing the significant models with the highest coefficient of determination $\left(\mathrm{R}^{2}\right)$. For statistical analysis, the $\operatorname{SISVAR}^{\circledR}$ (Ferreira, 2011) computer program was used.

\section{Results and Discussion}

\subsection{Phosphate Maximum Adsorption Capacity and Clay Fraction Mineralogy}

The soils presented different behavior to PAC (Table 2). There was a proportional increase of the adsorbed P as a function of the applied doses in both studied soils. However, in the Red-Yellow Latosol (RYL), the adsorption potential was three fold higher the PAC of the Typic Hapludalf (TH) (Figure 1) that has with a sandy clay loam texture, as expected. In this way, the $\mathrm{P}$ adsorption varied, following the specific intrinsic characteristics (texture, mineralogy, and $\mathrm{P}$ content) to each soil.

Table 2. Linear equation of the Langmuir isotherm (maximum capacity constant and adsorption energy), maximum phosphorus adsorption capacity (PAC), and adsorption energy in Red-yellow latosol (RYL) and Typic Hapludalf (TH)

\begin{tabular}{|c|c|c|c|c|c|c|c|}
\hline Soils & Sand & Silt & Clay & Regression equation $^{(1)}$ & $\mathrm{R}^{2}$ & $\mathrm{PAC}^{(2)}$ & Adsorption energy \\
\hline & \multicolumn{5}{|c|}{------------ g kg$^{-1}$------------ } & $--\mathrm{mg} \mathrm{dm}^{-3}--$ & ----- $\mathrm{L} \mathrm{mg}^{-1}$ \\
\hline LV & 229 & 81 & 690 & $\mathrm{y}=8.7496+1.5471 \mathrm{x}$ & 0.98 & 650 & 0.1768 \\
\hline PVA & 644 & 82 & 314 & $\mathrm{y}=23.58+4.5737 \mathrm{x}$ & 0.99 & 220 & 0.1939 \\
\hline
\end{tabular}



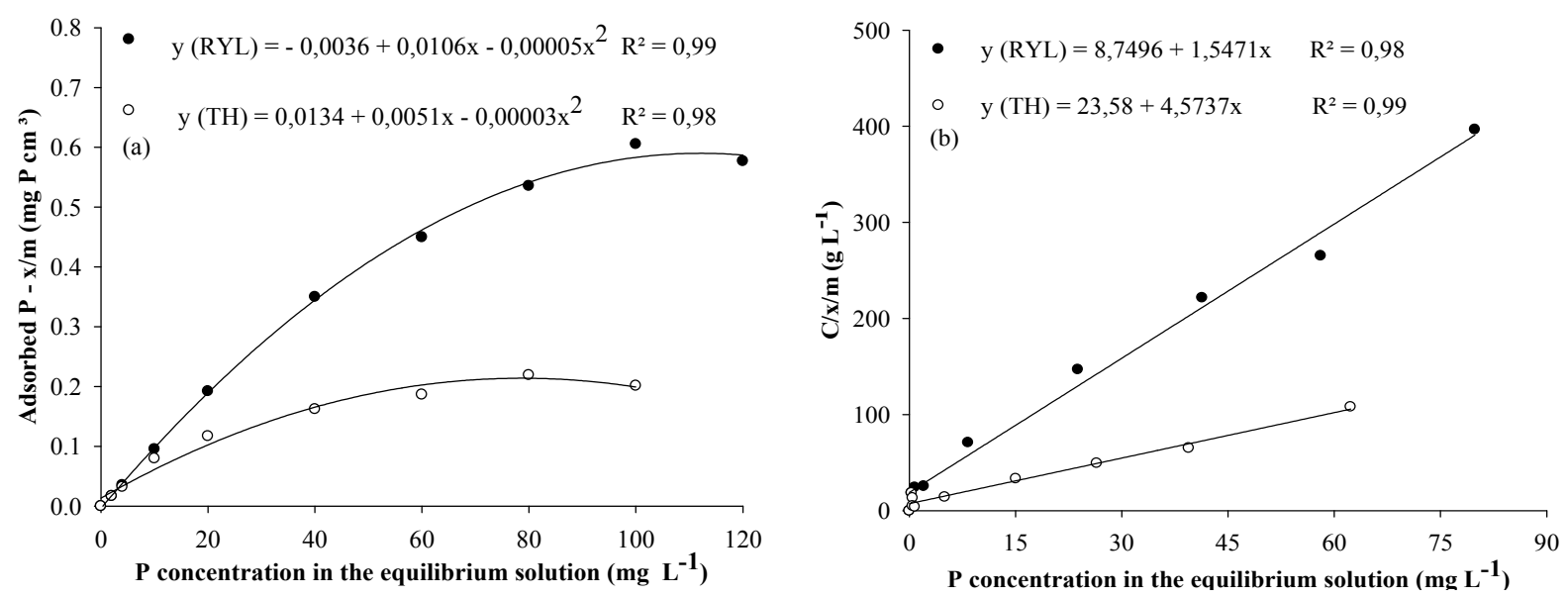

Figure 1. Phosphorus adsorption isotherms in hyperbolic (a) and linear (b) forms of RYL and TH

Linearizing data we were able to observe the precision of the results through the coefficient of determination $\left(\mathrm{R}^{2}\right)$ values of RYL and TH, in the order of 0.98 and 0.99 , respectively (Table 2). However, the TH higher adsorption energy, whose saturation happened at $220 \mathrm{mg} \mathrm{dm}^{-3}$ of adsorbed $\mathrm{P}$, reveals difference in the mineralogical constitution of the clay fraction, consistent with similar studies (Simões Neto et al., 2009; Corrêa et al., 2011; Oliveira, Gatiboni, Miquelluti, Smyth, \& Almeida, 2014; Camargo et al., 2015).

According to X-ray diffraction spectra (XRD) the clay fraction mineralogy of both soils was constituted by oxides of hematite $(\mathrm{Hm})$, goethite $(\mathrm{Gt})$, gibbsite $(\mathrm{Gb})$, and silicate as kaolinite $(\mathrm{Kt})$, in specific proportions (Table 3 and Figure 2). The Gt and Gb domain at RYL (Figures $2 a$ and $2 b$ ), as revealed by the well-defined and more expressive peaks, explaining the higher concentrations of $650 \mathrm{mg} \mathrm{dm}^{-3}$ of adsorbed P. Similar results were found in similar studies by Simões Neto et al. (2009), which found high PAC in oxidic soils, compared to kaolinites. This is because the $\mathrm{Ct}$ has its adsorption potential limited only to the outer surface, which gives it low specific surface values (Schoonheydt \& Johnston, 2011), which resulted in the lowest PAC, that is, $220 \mathrm{mg} \mathrm{dm}^{-3}$ in TH (Table 2).

Table 3. Crystallographic parameters and mineral content of the clay fraction of Red-yellow Latosol (RYL) and Typic Hapludalf (TH)

\begin{tabular}{|c|c|c|c|c|c|c|c|c|c|c|c|c|c|c|c|}
\hline & \multicolumn{3}{|c|}{ MCD } & \multicolumn{3}{|c|}{ HHW } & \multicolumn{2}{|l|}{ SSE } & \multicolumn{2}{|l|}{ IS } & \multirow{2}{*}{$\begin{array}{l}\text { Ratio } \\
\text { di* }^{*}\end{array}$} & \multicolumn{4}{|c|}{ Content } \\
\hline & ${ }^{\circ} 2 \theta$ & & & & & & $\mathrm{m}^{2} \mathrm{~g}^{-1}$ & & $\mathrm{~mol} \%$ & & & $\mathrm{~g} \mathrm{~kg}^{-1}$ & & & \\
\hline Soil & $\mathrm{Gt}_{110}$ & $\mathrm{Gt}_{111}$ & $\mathrm{Hm}_{110}$ & $\mathrm{Hm}_{012}$ & $\mathrm{Ct}$ & $\mathrm{Gb}$ & $\mathrm{Gt}$ & $\mathrm{Hm}$ & $\mathrm{Gt}$ & $\mathrm{Hm}$ & $\mathrm{Ct} /(\mathrm{Ct}+\mathrm{Gb})$ & Fed & Feo & Gt & $\mathrm{Hm}$ \\
\hline RYL & 38.6 & 12.8 & 39.3 & 106 & 0.60 & 0.29 & 106 & 47.58 & 32.01 & 18.97 & 0.62 & 47.68 & 0.51 & 43.4 & 24.7 \\
\hline $\mathrm{TH}$ & 22.4 & 7.12 & 29.6 & 56.8 & 0.53 & 0.31 & 78 & 42.24 & 20.52 & 10.41 & 0.74 & 16.98 & 0.26 & 35.5 & 8.2 \\
\hline
\end{tabular}

Note. $\mathrm{di}=$ dimensionless. 

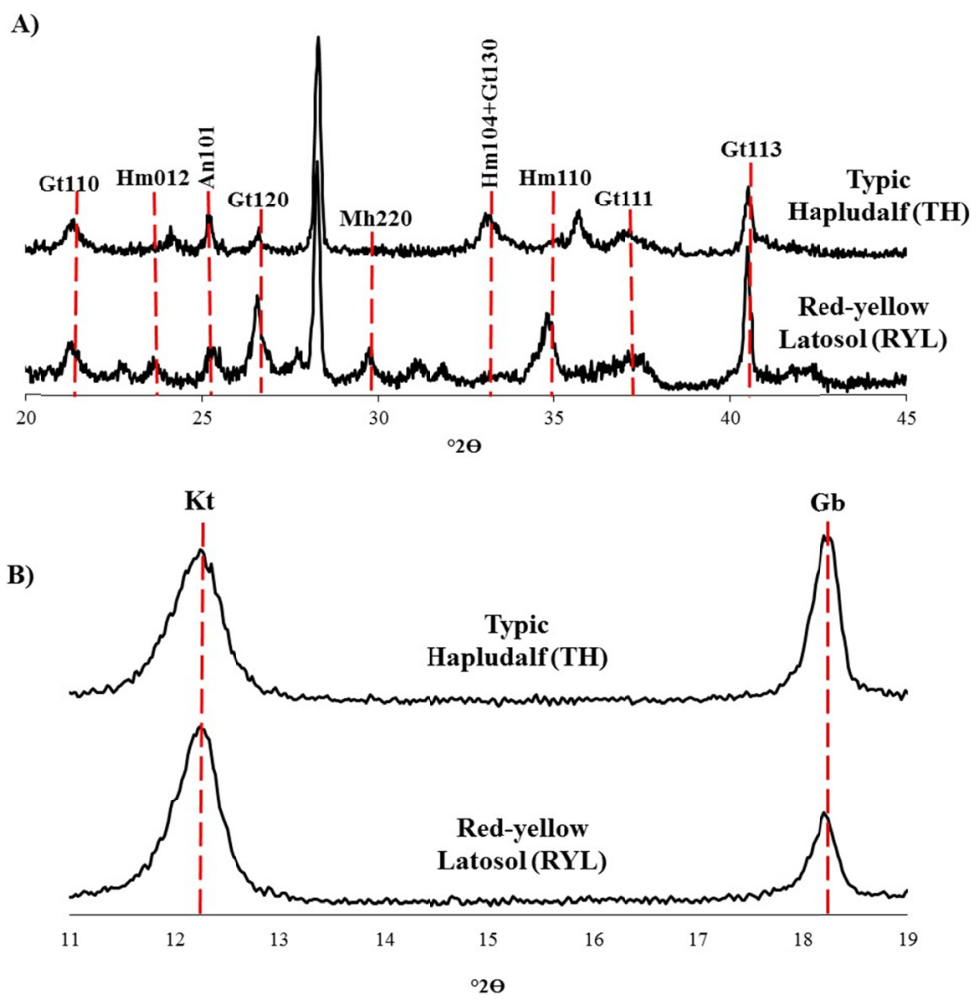

Figure 2. Clay fraction X-ray diffractograms in A): after concentration of goethite iron oxides (Gt), hematite $(\mathrm{Hm})$ and maghemite $(\mathrm{Mh})$ and $\mathrm{B})$ : kaolinite $(\mathrm{Kt})$ and gibbsite $(\mathrm{Gb})$ of the soils used in the experiment

When we evaluated the crystallographic parameters, we observed that the lower values of MDC (Mean Diameter of Crystallite) and higher HHW (Half Height Width) indicate $\mathrm{Fe}$ and $\mathrm{Al}$ oxide forms persistence, which are less crystalline minerals in TH (Table 3). According to Fink et al. (2016), these forms are more reactive in the P adsorption due to the higher exposed surface charge density $\left(\mathrm{OH}^{-}\right)$. Probably this may have been the cause of higher adsorption energy value obtained in $\mathrm{TH}$. However, the kaolinite effectiveness $\mathrm{Ct} /(\mathrm{Ct}+\mathrm{Gb})=0.74$, together to the lower clay content in the general balance, gave lower PAC, since $50 \%$ of the kaolinite net surface charge is essentially negative, non-reactive with phosphate anionic groups (Santos et al., 2008) and it has limited surface load (Schoonheydt \& Johnston, 2011). This indicates the need for smaller phosphate fertilizations to meet the plant need and guarantee the crop productivity in TH. Considering that the P adsorption has a strong relation with the soil clay content (Falcão \& Silva, 2004; Machado, De Souza, De Andrade, Lana, \& Korndorfer, 2011; Santos, Oliveira, Salcedo, Souza, \& Silva, 2011; Barrow, 2015). This fact was also observed, once the higher absorption happened in RYL, a clayed soil $\left(690 \mathrm{~g} \mathrm{~kg}^{-1}\right)$, governed by the higher content of goethite oxides, hematite, and gibbsite (Table 3).

Dealing with the minerals contribution in PAC, regardless the soil type, the MCD110 (22-38 nm) and MCD111 $(7-12 \mathrm{~nm})$ crystallites smaller dimensions for Gt related to Hm with MCD110 (29-39 nm) and MCD (56-106 nm) indicated low crystallinity Gt. This behavior is due to the predisposition of Gt to substitute Fe (ionic radius = 0.065 ) by Al (ionic radius $=0.053$ ) in its structure (McLaughlin, Mulrine, Gresalfi, \& McLaughlin, 1981), providing the unit cell contraction and, consequently, the specific surface area (SSA) increasing (Barbieri et al., 2014). The high SSA selected Gt the main oxide responsible for $P$ adsorption and much higher PAC in the studied soils, given the higher predisposition of free adsorption sites to phosphates (Magalhães Moreira, Bastos Mota, Clemente, Moreira de Azevedo, \& Vieira do Bomfim, 2006). As an example, Almeida, Torrent, and Barrón (2003) evaluating the hematite and goethite participation in phosphates adsorption by Oxisols developed from Basalt in southern Brazil, verified a lower sorption capacity of $\mathrm{P}$ where hematite prevailed to goethite.

\subsection{Soybean Response to P Doses in the Soil}

The phosphorus application based on PAC of each soil resulted in an increase in available P (Pavail) levels in both soils, influencing directly the height and root volume of soybean plants at 91 days (DAE) (Table 4). In the soil, the Pavail levels increased proportionally with the applied P up to $24 \%$ (maximum dose of the treatment), 
while in the plant, the contents of $\mathrm{P}$ presented a maximum content provided by the dose of $\mathrm{P}$ applied in $17 \%$ of PAC in both soils. Corrêa, Mauad and Rosolem (2004) cultivating soybean in pots also verified increase in soil Pavail as a result of the application of increasing doses of $\mathrm{P}$ in Typic Haplorthox. Considering that the $\mathrm{P}$ applied doses were only up to (24\% of PAC) $1 / 4$ of the expected saturation of both soils, it was expected that the Pavail levels would present such behavior, i.e., a linear increase at the applied doses, however enough to promote maximum absorption by plants.

Table 4. Available phosphorus (Pavail) in soil, Plant P accumulation (PP), and height (H) of soybean plants, as a function of the $\mathrm{P}$ doses application based on soil PAC

\begin{tabular}{|c|c|c|c|c|}
\hline$\%$ of PAC applied & Soil $\mathrm{P}$ available & Plant P & $\mathrm{H}$ & RV \\
\hline & $\mathrm{mg} \mathrm{dm}^{-3}$ & $\mathrm{~g} \mathrm{~kg}^{-1}$ & $\mathrm{~cm}$ & $\mathrm{~cm}^{3}$ plant $^{-1}$ \\
\hline 0 & 3.85 & 0.85 & 36.7 & 6.29 \\
\hline 1 & 10.71 & 0.87 & 43.8 & 16.66 \\
\hline 6 & 11.71 & 0.96 & 45.3 & 18.33 \\
\hline 12 & 23.10 & 1.07 & 55.0 & 19.66 \\
\hline 24 & 36.04 & 1.05 & 60.7 & 19.83 \\
\hline RYL & $16.61 \mathrm{a}$ & $0.93 \mathrm{a}$ & $47.6 \mathrm{a}$ & $20.03 \mathrm{a}$ \\
\hline \multirow[t]{2}{*}{ TH } & $17.33 \mathrm{a}$ & $0.99 \mathrm{a}$ & $49.0 \mathrm{a}$ & $12.01 \mathrm{~b}$ \\
\hline & \multicolumn{4}{|c|}{ 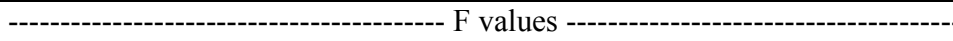 } \\
\hline Soil & $0.528 \mathrm{~ns}$ & $4.22 \mathrm{~ns}$ & $0.63 \mathrm{~ns}$ & $30.44 * *$ \\
\hline$(\mathrm{P})$ & $130.32 * *$ & $9.67 * *$ & $23.47 * *$ & $11.37 * *$ \\
\hline$(\mathrm{P}) \times$ Soil & $0.96 \mathrm{~ns}$ & $1.44 \mathrm{~ns}$ & $7.16^{* *}$ & $5.02 * *$ \\
\hline $\mathrm{CV}(\%)$ & 16.08 & 8.14 & 9.96 & 25.0 \\
\hline
\end{tabular}

Note. F test: $\mathrm{ns}, *, * *$, non significant and significant at 5 and $1 \%$. CV\%: coefficient of variation. Means followed by the same lowercase letter in the column do not differ between each other respectively by $\mathrm{F}$ test and Tukey test at $5 \%$ of probability.

Based on this assumption, the Pavail levels in the soils increased linearly as a function of the applied P doses, from $3.85 \mathrm{mg} \mathrm{dm}^{-3}$ in the control treatment ( $0 \%$ of PAC) to $36.04 \mathrm{mg} \mathrm{dm}^{-3}$ with P at $24 \%$ of PAC, increasing the Pavail levels by $89 \%$ (Figure 3). Such event is directly related to the equilibrium promoted by $\mathrm{P}$ in the soil when applied, saturating part of the fixation sites. Thus, the application of the P based on PAC provided precise results of $\mathrm{P}$ amount to be applied, since the Pavail levels did not differ between the soil classes (Table 4). The increase of Pavail in the soil favored the P uptake by the plants, a fact evidenced by the $\mathrm{P}$ contents increase in the plant tissue concomitantly the $\mathrm{P}$ doses used in the soil (Table 4). However, unlike the soil, the plant P contents results in adjusted to the quadratic model, with inflection point from the dose estimated in $17 \%$ of the PAC, obtaining $1.07 \mathrm{~g} \mathrm{~kg}^{-1}$ of $\mathrm{P}$ in the soybean dry matter for both soils (Figure 3).

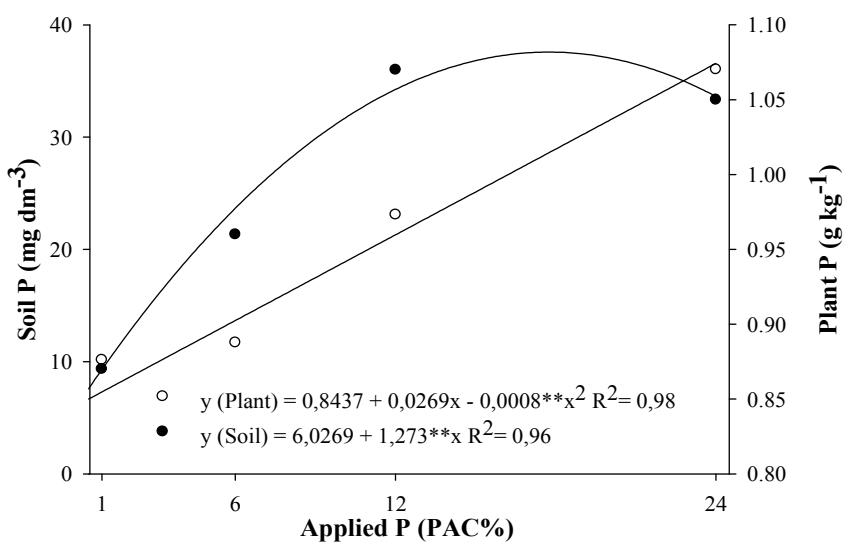

Figure 3. Soil $\mathrm{P}$ available and $\mathrm{P}$ accumulation in the plant tissue of soybean plants as a function of $\mathrm{P}$ application based on percentages of the maximum adsorption capacity of P (PAC) of each soil. **: significant at $1 \%$ probability by $\mathrm{F}$ test 
Corrêa et al. (2004) evaluating crescent doses of $\mathrm{P}\left(0,229,458\right.$, and $687 \mathrm{~kg} \mathrm{ha}^{-1}$ of $\left.\mathrm{P}_{2} \mathrm{O}_{5}\right)$ on the $\mathrm{P}$ content in the soybean tissue showed a maximum content of $1.3 \mathrm{~g} \mathrm{~kg}^{-1}$ of $\mathrm{P}$ in the dry matter, provided at $206 \mathrm{~kg} \mathrm{ha}^{-1} \mathrm{P}_{2} \mathrm{O}_{5}$ dose The results obtained in this study suggest that, at $17 \%$ of PAC, soil Pavail levels reach the critical range for higher P uptake by soybean. When this occurs, phosphate fertilizations in later crops can be made in equivalence to that exported by grains and plant (Vieira, Fontoura, Bayer, Moraes, \& Carniel, 2015; Yang, Xu, Wang, Ma, Wei, \& He, 2017).

For plant height, there was interaction between doses of $\mathrm{P} \times$ soil (Table 5). In the absence of $\mathrm{P}$ application (dose 0 ) in the soils, the highest height of plants was observed in TH. On the other hand, in $12 \%$ of the PAC, the highest height occurred in RYL. There were no differences between soils in the other doses evaluated.

Table 5. Effect of P doses based on PAC of two soils, on the soybean plant height $(\mathrm{cm})$

\begin{tabular}{lllllll}
\hline \multirow{2}{*}{ Soil } & \multicolumn{5}{c}{ P doses in \% of PAC } & \multirow{2}{*}{ F value } \\
\cline { 2 - 5 } & 0 & 1 & 6 & 12 & 24 & $25.6 * *$ \\
RYL & $27.5 \mathrm{bC}$ & $42.5 \mathrm{aB}$ & $46.2 \mathrm{aB}$ & $60.0 \mathrm{aA}$ & $61.8 \mathrm{aA}$ & $5.1 * *$ \\
TH & $45.8 \mathrm{aB}$ & $45.2 \mathrm{aB}$ & $44.5 \mathrm{aB}$ & $50.0 \mathrm{bAB}$ & $59.5 \mathrm{aA}$ & $0.35 \mathrm{~ns}$ \\
\hdashline F value & $21.8 * *$ & $0.46 \mathrm{~ns}$ & $0.18 \mathrm{~ns}$ & $6.49 *$ & & \\
MSD line & 11.75 & & & & \\
Column & 8.19 & & & & & \\
\hline
\end{tabular}

Note. F test: ns, *, **, non significant and significant at 5 and $1 \%$. Means followed by the same lowercase letter in the column do not differ between each other respectively by $\mathrm{F}$ test and Tukey test at $5 \%$ of probability.

Observing the interaction unfolding results in each soil (Figure 4) we observed that in RYL the quadratic function was adjusted, obtaining maximum height $(63.65 \mathrm{~cm})$ at the estimated P-dose in $19 \%$ of PAC. On the other hand, in TH this response was linear, corroborating the results of Soares, Sediyama, Neves, Júnior and Silva (2016). Such observed characteristic in TH can be attributed to a more kaolinite mineralogy, due to the lower adsorption potential of this mineral. Valadão Júnior et al. (2008), and Araújo et al. (2008), applying P in a Typical Haplorthox, based on the expected soybean yield, found maximum plant height at $140 \mathrm{~kg} \mathrm{ha}^{-1} \mathrm{P}_{2} \mathrm{O}_{5}$ and $192.07 \mathrm{~kg} \mathrm{ha}^{-1} \mathrm{P}_{2} \mathrm{O}_{5}$, respectively. These possible differences found for the same soil class are strongly influenced by mineralogy, which differentiates between soils, reinforcing the need to know this attribute, in order to estimate PAC and, consequently, conduct the strategic management of phosphate fertilizers (Peluco et al., 2015; Withers et al., 2018).

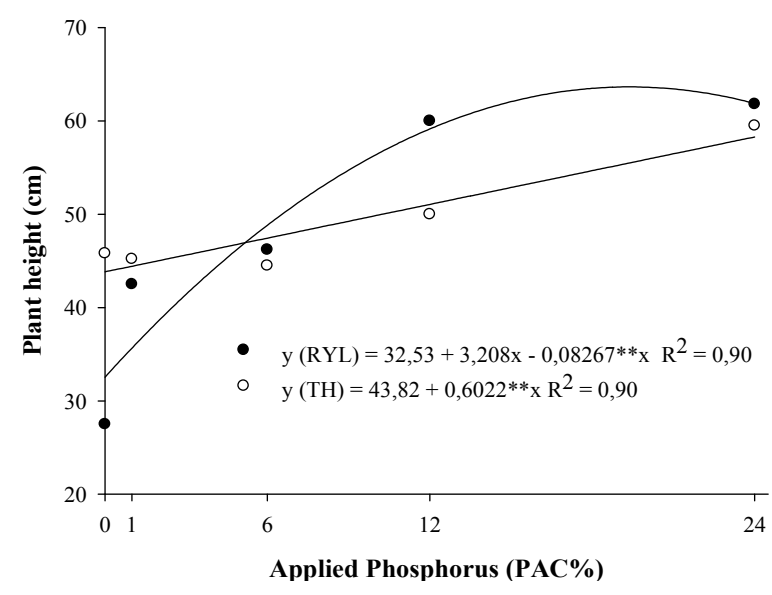

Figure 4. Soybean plants height as a function of phosphorus application based on percentages of the maximum adsorption capacity of $\mathrm{P}(\mathrm{PAC})$ of each soil. **: significant at $1 \%$ probability by $\mathrm{F}$ test

Similar to plant height, there was interaction between doses of $\mathrm{P} \times$ soil, on root volume (Table 4). Except to the $\mathrm{P}$ absence where the root volume was higher in RYL. The root volume in this soil $\left(20.03 \mathrm{~cm}^{3}\right)$, in average, was 
$60 \%$ higher than that found in TH $\left(12.01 \mathrm{~cm}^{3}\right)$. When we observed the effect of the doses on each soil (Table 6), there was a linear increase of the root volume at TH. We can infer that this soil, besides being more responsive to phosphate fertilizers, presented better conditions for the roots development, like lower resistance to penetration and higher soil exploration by roots due to its lower clay content (Figure 5).

Table 6. Effect of P doses based on the PAC of two soils, on the root volume $\left(\mathrm{cm}^{3}\right.$ plant $\left.{ }^{-1}\right)$ of soybean

\begin{tabular}{|c|c|c|c|c|c|c|}
\hline \multirow{2}{*}{ Soil } & \multicolumn{5}{|c|}{$\mathrm{P}$ applied in $\%$ of PAC } & \multirow{2}{*}{ F value } \\
\hline & 0 & 1 & 6 & 12 & 24 & \\
\hline RYL & $3.83 \mathrm{aB}$ & $23.33 \mathrm{aA}$ & $23.67 \mathrm{aA}$ & $26 \mathrm{aA}$ & $24.66 \mathrm{aA}$ & $15.22 * *$ \\
\hline $\mathrm{TH}$ & $8.75 \mathrm{aA}$ & $10.0 \mathrm{bA}$ & $13.0 \mathrm{bA}$ & $13.33 \mathrm{bA}$ & $15 \mathrm{bA}$ & $1.16 \mathrm{~ns}$ \\
\hline F value & $2.14 \mathrm{~ns}$ & $15.76^{* *}$ & $10.10 * *$ & $14.23 * *$ & $8.28 * *$ & \\
\hline MSD line & 10.05 & & & & & \\
\hline Column & 7.004 & & & & & \\
\hline
\end{tabular}

Note. F test: ns, * **, non significant and significant at 5 and $1 \%$. Means followed by the same lowercase letter in the column do not differ between each other respectively by $\mathrm{F}$ test and Tukey test at $5 \%$ of probability.

In turn, there was a quadratic function adjustment in RYL, with an estimated maximum root volume in $16 \%$ of PAC (Figure 5). According to Pavinato et al. (2009), phosphorus has low mobility in the soil and high capacity of fixation by the clays. This certainly hinders root contact with the nutrient and its absorption, thus inhibiting root growth. However, we could observed that increasing the P doses, part of the adsorptive sites were saturated, weakening the $\mathrm{P}$ affinity for the soil, which resulted in an increase in the Pavail, and consequently the root development improvement regardless of the soil.

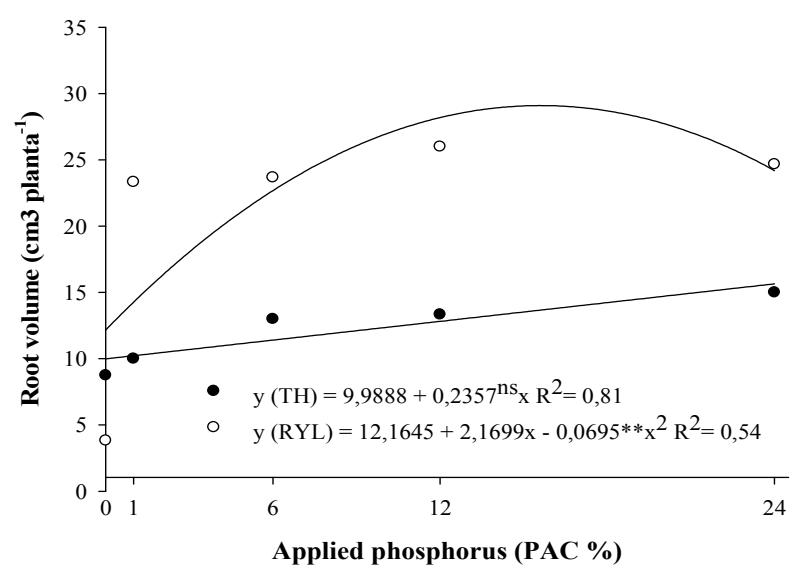

Figure 5. Soybean root volume as a function of phosphorus application based on percentages of the maximum adsorption capacity of $\mathrm{P}(\mathrm{PAC})$ of each soil. **: significant at $1 \%$ probability by $\mathrm{F}$ test

$\mathrm{P}$ doses applied using PAC as a parameter provided increases in the number of pods per plant (PP), root (RDM) and aerial (ADM) dry mass, and total dry mass (TDM) (Table 7). However, a variable behavior was observed for the different soils evaluated in this study. Similar responses were observed in the number of PP, ADM and TDM, which were higher in TH, whereas RDM decreased. 
Table 7. Soybean pod production per plant (PP), root dry mass (RDM), root volume (RDM), aerial dry mass (ADM), and total dry mass (TDM) as a function of the application of $\mathrm{P}$ doses based on the soil PAC

\begin{tabular}{|c|c|c|c|c|}
\hline (P) applied $\%$ of PAC & PP & RDM & $\mathrm{ADM}$ & TDM \\
\hline & unit & \multicolumn{3}{|c|}{ 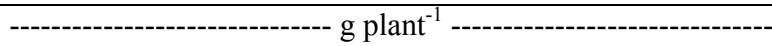 } \\
\hline 0 & 8.0 & 0.74 & 2.76 & 3.50 \\
\hline 1 & 17.0 & 2.36 & 6.37 & 8.72 \\
\hline 6 & 21.0 & 2.76 & 8.79 & 11.56 \\
\hline 12 & 25.0 & 2.92 & 10.03 & 12.95 \\
\hline 24 & 27.0 & 2.94 & 12.06 & 14.99 \\
\hline \multicolumn{5}{|l|}{ Soil } \\
\hline RYL & $13.0 \mathrm{~b}$ & $2.62 \mathrm{a}$ & $6.0 \mathrm{~b}$ & $8.62 \mathrm{~b}$ \\
\hline \multirow[t]{2}{*}{$\mathrm{PH}$} & $26.0 \mathrm{a}$ & $2.06 \mathrm{~b}$ & $10.0 \mathrm{a}$ & $12.07 \mathrm{a}$ \\
\hline & ------ & -------- & lues -----. & -----------------------. \\
\hline Soil & $87.31 * *$ & $10.26 * *$ & $60.75 * *$ & $33.16^{* *}$ \\
\hline (P) & $23.25 * *$ & $23.04 * *$ & $39.05 * *$ & $44.38 * *$ \\
\hline$(\mathrm{P}) \times$ Soil & $0.45 \mathrm{~ns}$ & $4.09 * *$ & $0.13 \mathrm{~ns}$ & $0.76 \mathrm{~ns}$ \\
\hline $\mathrm{CV}(\%)$ & 19.65 & 20.16 & 17.54 & 15.83 \\
\hline
\end{tabular}

Note. F test: ns, *, **, non significant and significant at 5 and $1 \%$. CV\%: coefficient of variation. Means followed by the same lowercase letter in the column do not differ between each other respectively by $\mathrm{F}$ test and Tukey test at $5 \%$ of probability.

In both soils, pod production responded linearly to $\mathrm{P}$ doses (Figure 6), from 8 pods per plant in the control treatment $(0 \%$ of PAC) to 27 at the maximum $\mathrm{P}$ dose tested $(24 \%$ of PAC). This is a $70 \%$ increase due to the $\mathrm{P}$ fertilization. This way, in agreement to other investigations (Zhang et al., 2010; Cruz, Souza Filho, \& Pelacani, 2015), soils with low P availability provide lower number of flowers and a higher pod abortion, compromising productivity. In this sense, Batistella Filho, Ferreira, Vieira, and Cruz (2013) also obtained a linear response for soybean pod production in Typic Haplortox up to the maximum test dose of $160 \mathrm{~kg} \mathrm{ha}^{-1}$ of $\mathrm{P}_{2} \mathrm{O}_{5}$. Being pod the main organ responsible for the grain formation and development, it is expected that the linear increase of pods into the $\mathrm{P}$ doses up to $24 \%$ of PAC, will result in higher grain yield per plant.

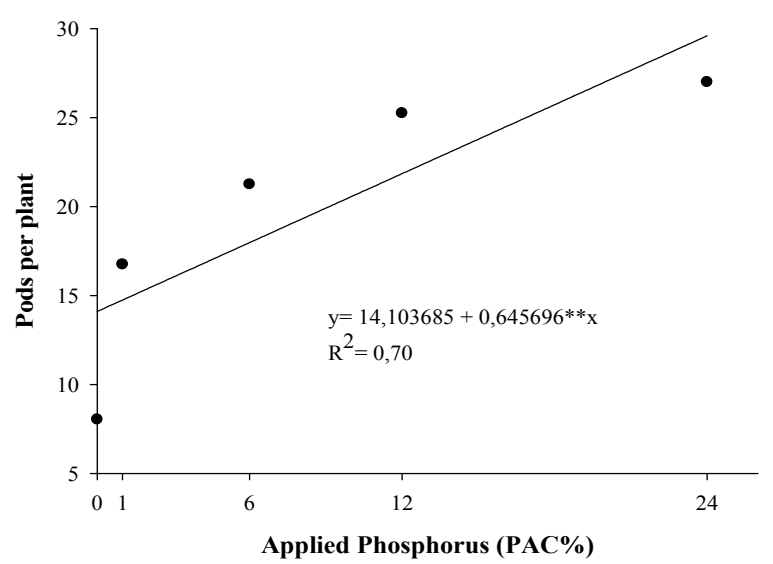

Figure 6. Number of pods per soybean plant as a function of phosphorus application based on percentages of the maximum adsorption capacity of $\mathrm{P}$ (PAC) of each soil. **: significant at $1 \%$ probability by $\mathrm{F}$ test

Regarding to RDM, we observed interaction between $\mathrm{P}$ doses $\times$ soil (Table 7). Among the soils, the highest root dry mass weight was in RYL, provided by the $1 \%, 6 \%$, and $12 \%$ of PAC when compared to TH. In addition, there were no differences between soils in the absence of P and in $24 \%$ of PAC (Table 8 ). 
Table 8. P doses effect based on PAC of RYL and TH on the soybean root dry weight $\left(\mathrm{g} \mathrm{plant}^{-1}\right)$

\begin{tabular}{lllllll}
\hline \multirow{2}{*}{ Soil } & \multicolumn{5}{c}{ P applied \% of PAC } & F value \\
\cline { 2 - 6 } & 0 & 1 & 6 & 12 & 24 & $22.60^{* *}$ \\
\hline RYL & $0.35 \mathrm{aB}$ & $2.77 \mathrm{aA}$ & $3.20 \mathrm{aA}$ & $3.54 \mathrm{aA}$ & $3.23 \mathrm{aA}$ & $4.53^{* *}$ \\
TH & $1.13 \mathrm{aB}$ & $1.94 \mathrm{bB}$ & $2.32 \mathrm{bA}$ & $2.29 \mathrm{bA}$ & $2.64 \mathrm{aA}$ & \\
\hline F value & $4.05 \mathrm{~ns}$ & $4.66^{*}$ & $5.12^{*}$ & $10.49^{* *}$ & $2.28 \mathrm{~ns}$ & \\
MSD line & 1.15 & & & & & \\
Column & 0.80 & & & & & \\
\hline
\end{tabular}

Note. F test: ns, ${ }^{*}, * *$, non significant and significant at 5 and $1 \%$. Means followed by the same lowercase letter in the column do not differ between each other respectively by $\mathrm{F}$ test and Tukey test at $5 \%$ of probability.

However, when we verified the effect of the doses in each soil, the RDM production in TH increased linearly until the maximum dose tested (24\% of PAC) equivalent to $220 \mathrm{~kg}_{\text {of }} \mathrm{P}_{2} \mathrm{O}_{5} \mathrm{ha}^{-1}$, considering the $0-0.20 \mathrm{~m}$ layer. On the other hand, the RDM in RYL production adjusted in a quadratic manner, with maximum yield obtained at the P-dose estimated at $15 \%$ of PAC, corresponding to $450 \mathrm{~kg}$ of $\mathrm{P}_{2} \mathrm{O}_{5} \mathrm{ha}^{-1}$ (Figure 7a), which resulted in the increase of $91 \%$ in the RDM (3.98 $\left.\mathrm{g} \mathrm{plant}^{-1}\right)$ compared to the absence of $\mathrm{P}$ application $\left(0.35 \mathrm{~g} \mathrm{plant}^{-1}\right)$. The TH results resemble those of Corrêa et al. (2004), who also observed a linear adjustment in the RDM to soybean up to the dose of $150 \mathrm{~kg} \mathrm{ha}^{-1}$ of $\mathrm{P}$, equivalent to $343 \mathrm{~kg}$ of $\mathrm{P}_{2} \mathrm{O}_{5} \mathrm{ha}^{-1}$.

The aerial part responses were different from those obtained in the roots, between the soils. The TH PAC $(10 \mathrm{~g}$ plant $^{-1}$ ) was $60 \%$ higher than the RYL $\left(4.0 \mathrm{~g} \mathrm{plant}^{-1}\right)$ (Table 7). This fact can be attributed to the mineralogical characteristic of $\mathrm{TH}$, which was predominantly kaolinite, and therefore the specific surface area of kaolinite is limited only to external surfaces, which gives it low adsorption value (Schoonheydt \& Johnston, 2011). However, the effect of employed $\mathrm{P}$ doses showed the same behavior in both soils, with PAC adjusting the quadratic function, and maximum yield (12.10 $\left.\mathrm{g} \mathrm{plant}^{-1}\right)$ estimated in $21 \%$ of PAC (Figure $\left.7 \mathrm{~b}\right)$. This production represents an increase of $77 \%$ when compared to the $0 \%$ of PAC ( $\left.2.76 \mathrm{~g} \mathrm{plant}^{-1}\right)$. These results are similar to Bonfim-Silva et al. (2014) ones, which obtained a $55 \%$ increase in the dry mass of aerial part of the soybean in relation to the control soil. 

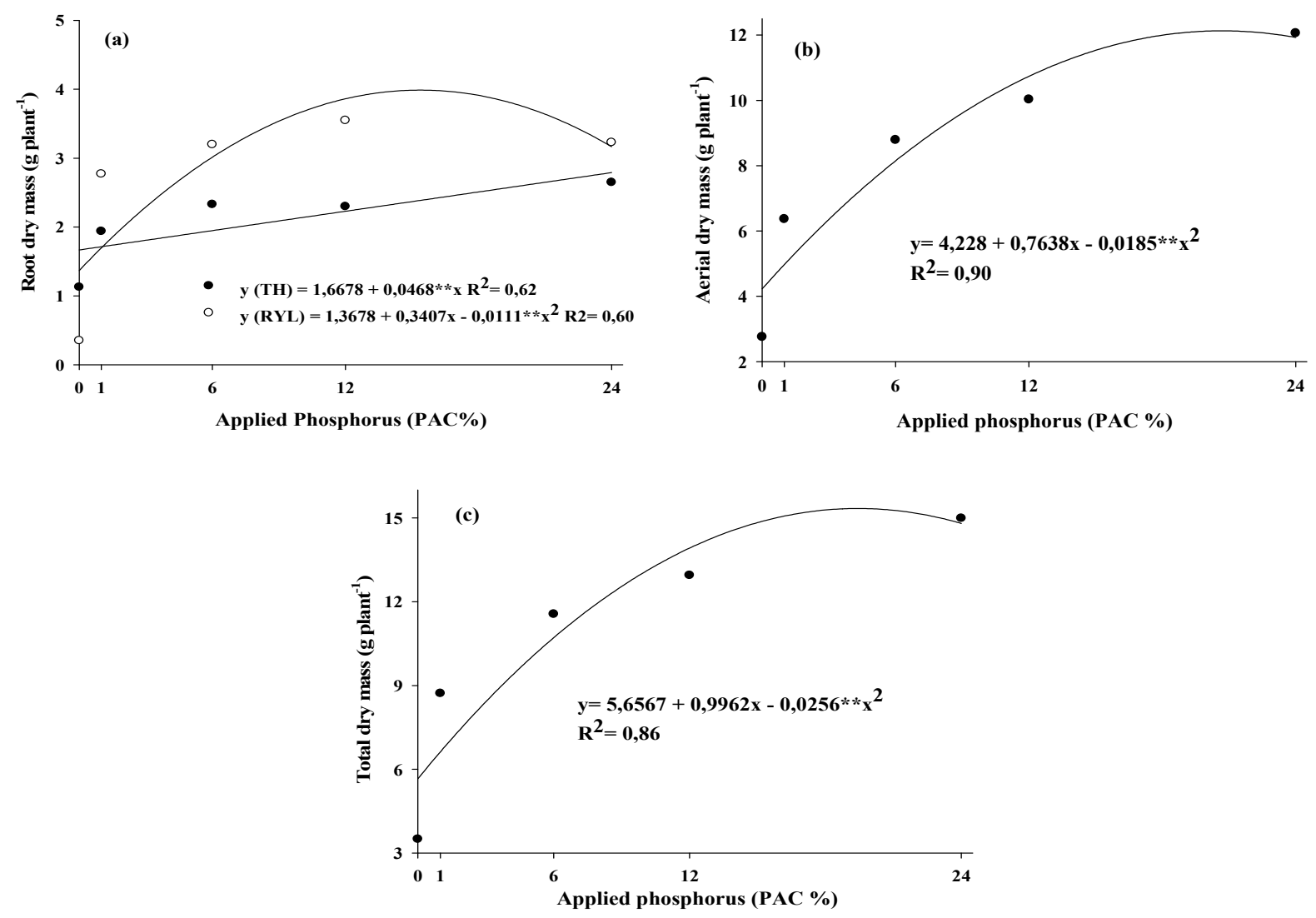

Figure 7. P doses Effect based on PAC of RYL and TH on root dry mass (7a), aerial dry mass (7b) and total dry matter (7c) production in soybean plants at R4 (full pod formation)stage of development (pods full formation). $* *$ : significant at $1 \%$ probability by $\mathrm{F}$ test

Regarding to the Total Dry mass of the plant (TDM) in the different soils (Table 7) we could verify that in TH the average TDM (12.07 g plant $\left.{ }^{-1}\right)$ was $28 \%$ higher than that observed in RYL $\left(8.62 \mathrm{~g} \mathrm{plant}^{-1}\right)$. This result is directly related to root and shoot development. Facing this, the strong increase in PAC occurred in TH certainly contributed to the mentioned increase. However, the P doses effect based on PAC were similar to both soils (Table 7). The maximum accumulation of TDM occurred in 19.45\% of PAC, decreasing thereafter (Figure 7c), that is, for the development of soybean independently of the soil, the greater probability of dry mass gains can be reached when P fertilization is done aiming 19\% of PAC. The P fertilization effect is very important, especially in new crop regions, where soil phosphorus levels are low, such as Amazon and Cerrado soils (Cantarella, Correa, O. Primavesi, \& A. C. Primavesi, 2002; Guedes et al., 2018).

In a general way, the aforementioned results indicate that the use of soil PAC as a P quantity factor to be applied is able to aid the current methods of phosphate fertilization recommendation to soybean in Cerrado soils. The PAC provided the range in which the plants have a better response to fertilization, mitigating the soil expected variations. Thus the recommendations based on PAC allowed compartmentalizing different production environments, when we considered the soil potential to adsorb phosphate based on its mineralogy.

\section{Conclusions}

The soils PAC ranged from 220 to $650 \mathrm{mg} \mathrm{dm}^{-3}$, with higher value in RYL associated to the oxidic mineralogy and clay texture in relation to $\mathrm{TH}$ of kaolinite origin and sandy texture.

Phosphorus fertilizing from 16 to $21 \%$ of PAC, regardless the soil, promotes the same pattern of response with improvements in soybean development, evidenced by plant height, root volume, and aerial dry mass increases.

\section{References}

Almeida, J. A., Torrent, J., \& Barrón, V. (2003). Cor de solo, formas do fósforo e adsorção de fosfatos em Latossolos desenvolvidos de basalto do extremo-sul do Brasil. Revista Brasileira de Ciência do Solo, 27(6), 985-1002. https://doi.org/10.1590/S0100-06832003000600003 
Araújo, W. F., Sampaio, R. A., \& De Medeiros, R. D. (2008). Resposta de cultivares de soja à adubação fosfatada, Revista Ciência Agronômica, 36(2), 129-134.

Barbieri, D. M., Marques Júnior, J., Siqueira, D. S., Teixeira, D. B., Panosso, A. R., Pereira, G. T., \& La Scala, N. (2014). Iron oxides and quality of organic matter in sugarcane harvesting systems. Revista Brasileira de Ciência do Solo, 38(4), 1143-1152. https://doi.org/10.1590/S0100-06832014000400010

Barrow, N. J. (2015). Soil phosphate chemistry and the P-sparing effect of previous phosphate applications. Plant and Soil, 397(1-2), 401-409. https://doi.org/10.1007/s11104-015-2514-5

Batistella Filho, F., Ferreira, M. E., Vieira, R. D., \& Cruz, M. C. P. (2013). Adubação com fósforo e potássio para produção e qualidade de sementes de soja. Pesquisa Agropecuária Brasileira, 48(7), 783-790. https://doi.org/10.1590/S0100-204X2013000700011

Bonfim-Silva, E. M., Guimarães, S. L., Farias, L. N., Oliveira, J. R., Bosa, C. K., \& Fontenelli, J. V. (2014). Adubação fosfatada no desenvolvimento e produção de feijão guandu em Latossolo vermelho do cerrado em primeiro cultivo. Bioscience Journal, 30(5), 1380-1388.

Bouma, T. J., Nielson, K. L., \& Koutstaal, B. A. S. (2000). Sample preparation and scanning protocol for computerized analysis of root length and diameter. Plant and Soil, 218(1-2), 185-196. https://doi.org/ 10.1023/A:1014905104017

Broggi, F., Oliveira, A. C., Freire, F. J., Freire, M. B. G. S., \& Nascimento, C. W. A. (2011). Fator capacidade de fósforo em solos de Pernambuco mineralogicamente diferentes e influência do $\mathrm{pH}$ na capacidade máxima de adsorção. Ciência e Agrotecnologia, 35(1), 77-83. https://doi.org/10.1590/S1413-70542011000100009

Caires, E. F., Sharr, D. A., Joris, H. A. W., Haliski, A., \& Bini, A. R. (2017). Phosphate fertilization strategies for soybean production after conversion of a degraded pastureland to a no-till cropping system. Geoderma, 308, 120-129. https://doi.org/10.1016/j.geoderma.2017.08.032

Camargo, L. A., Marques Júnior, J., Barrón, V., Alleoni, L. R. F., Barbosa, R. S., \& Pereira, G. T. (2015). Mapping of clay, iron oxide and adsorbed phosphate in Oxisols using diffuse reflectance spectroscopy. Geoderma, 251-252, 124-132. https://doi.org/10.1016/j.geoderma.2015.03.027

Cantarella, H., Correa, L. A., Primavesi, O., \& Primavesi, A. C. (2002). Fertilidade do solo em sistemas intensivos de manejo de pastagens. Proceedings of the Simpósio sobre Manejo de Pastagens. Inovações tecnológicas no manejo de pastagens (pp. 99-132). Piracicaba: FEALG.

Corrêa, J. C., Mauad, M., \& Rosolem, C. A. (2004). Fósforo no solo e desenvolvimento de soja influenciada pela adubação fosfatada e cobertura vegetal. Pesquisa Agropecuária Brasileira, 39(12), 1231-1237. https://doi.org/10.1590/S0100-204X2004001200010

Corrêa, M. R., Nascimento, D. C. W., \& Tavares, A. R. (2011). Adsorção de fósforo em dez solos do Estado de Pernambuco e suas relações com parâmetros físicos e químicos. Acta Scientiarum. Agronomy, 33(1), 153-159. https://doi.org/10.4025/actasciagron.v33i1.3129

Cruz, J. L., Souza Filho, L. F. S., \& Pelacani, C. R. (2015). Influência da adubação fosfatada sobre o crescimento do camapu (Physalis angulata L.). Revista Brasileira de Plantas Medicinais, 17(3), 360-366. https://doi.org/10.1590/1983-084X/13_060

Embrapa (Empresa Brasileira de Pesquisa Agropecuária). (2009). Manual de análises químicas de solos, plantas e fertilizantes (2nd ed.). Brasília, DF: Embrapa Informação Tecnológica.

Embrapa (Empresa Brasileira de Pesquisa Agropecuária). (2011). Manual de métodos de análise de solo (3th ed., p. 230). Embrapa Solos, Documentos, 132. Rio de Janeiro: Embrapa Solos.

Embrapa (Empresa Brasileira de Pesquisa Agropecuária). (2013). Sistema brasileiro de classificação de solos. Rio de Janeiro, RJ: Centro Nacional de Pesquisa em Solos.

Falcão, N. P. S., \& Silva, J. R. A. (2004). Características de adsorção de fósforo em alguns solos da Amazônia Central. Acta Amazonica, 34(3), 337-342. https://doi.org/10.1590/S0044-59672004000300001

Feba, L. T., Moro, E., \& Guerra, W. E. X. (2017). Soybean yield of degraded pasture after reimplantation with and without phosphating. African Journal of Agricultural Research, 12(32), 2566-2573. https://doi.org/ 10.5897/AJAR2017.12497

Fehr, W. R., \& Caviness, C. E. (1977). Stages of soybean development. Ames: Iowa State University of Science and Technology. 
Ferreira, D. F. (2011). Sisvar: A computer statistical analysis system. Ciência e Agrotecnologia, 35(6), 1039-1042. https://doi.org/10.1590/S1413-70542011000600001

Fink, J. R., Inda, A. V., Tiecher, T., \& Barrón, V. (2016). Iron oxides and organic matter on soil phosphorus availability. Ciência e Agrotecnologia, 40(4), 369-379. https://doi.org/10.1590/1413-70542016404023016

Gomes, R. P. (2017). Gênese, mineralogia e dinâmica do fósforo nos solos do Planalto Ocidental Paulista (Unpublished Master's Thesis, Faculdade de Ciências Agrárias e Veterinária, Universidade Estadual Paulista, Jaboticabal, Brazil).

Guedes, R. S., Fernandes, A. R., Souza, E. S. D., \& Silva, J. R. R. E. (2015). Maximum Phosphorus Adsorption Capacity Adjusted to Isotherm Models in Representative Soils of Eastern Amazon. Communications in Soil Science and Plant Analysis, 46(20), 2615-2627. https://doi.org/10.1080/00103624.2015.1089264

Guedes, R. S., Rodríguez-Vila, A., Forján, R., Covelo, E. F., \& Fernandes, A. R. (2018). Adsorption and risk of phosphorus loss in soils in Amazonia. Journal of Soils and Sediments, 18(3), 917-928. https://doi.org/ $10.1007 / \mathrm{s} 11368-017-1845-7$

Kämpf, N. (1981). Die eisenoxidmineralogie einer klimasequenz von böden aus eruptiva in Rio Grande do Sul, Brasilien (Unpublished Doctoral Dissertation, Freising Technische Universitat München, Munique, Germany).

Machado, V. J., De Souza, C. H. E., De Andrade, B. B., Lana, R. M. Q., \& Korndorfer, G. H. (2011). Curvas de disponibilidade de fósforo em solos com diferentes texturas após aplicação de doses crescentes de fosfato monoamônico. Bioscience Journal, 27(1), 70-76.

Magalhães Moreira, F. L., Bastos Mota, F. O., Clemente, C. A., Moreira de Azevedo, B.; \& Vieira do Bomfim, G. (2006). Adsorção de fósforo em solos do Estado do Ceará. Revista Ciência Agronômica, 37(1), 7-12.

Malavolta, E. (1981). Manual de química agrícola: Adubos e adubação (3th ed., p. 594). São Paulo: Editora Agronômica Ceres.

McLaughlin, S. N., Mulrine, T., Gresalfi, G. V., \& McLaughlin, A. (1981). Adsorption of divalent cations to bilayer membranes containing phosphatidylserine. Journal of General Physiology, 77(4), 445-473. https://doi.org/10.1085/jgp.77.4.445

Mehra, O. P., \& Jackson, M. L. (1960). Iron oxide removal from soils and clays by a dithionite citrate system buffered with sodium bicarbonate. In A. Swineford (Ed.), National conference on clays and clay mineral (pp. 317-342). Washington: Pergamon Press.

Melo, V. D. F., \& Alleoni, L. R. F. (2009). Química e mineralogia do solo (Parte I, Viçosa-MG, 529). Sociedade Brasileira de Ciência do Solo.

Norrish, K., \& Taylor, R. M. (1961). The isomorphous replacement of iron by aluminum in soil goethites. Journal Soil Science, 12(2), 294-306. https://doi.org/10.1111/j.1365-2389.1961.tb00919.x

Novais, R. F., \& Smyth, T. J. (1999). Fósforo no solo e planta em condições tropicais (p. 201). Viçosa: Universidade Federal de Viçosa.

Oliveira, C. M. B., Gatiboni, C. G., Miquelluti, D. J., Smyth, T. J., \& Almeida, J. A. (2014). Capacidade máxima de adsorção de fósforo e constante de energia de ligação em Latossolo bruno em razão de diferentes ajustes do modelo de Langmuir. Revista Brasileira de Ciência do Solo, 38(6), 1805-1815. https://doi.org/ 10.1590/S0100-06832014000600015

Olsen, S. R., \& Watanabe, F. S. (1957). A method to determine a phosphorus adsorption maximum of soils as measured by the Langmuir isotherm. Soil Science Society of America Journal, 21(2), 144-149. https://doi.org/10.2136/sssaj1957.03615995002100020004x

Paula, D. T., Martins, F. M. V., Farias, V. L., \& Siqueira, D. S. (2016). Clay and phosphorus losses by erosion in oxisol with sugarcane residues. Engenharia Agrícola, 36(6), 1063-1072. https://doi.org/10.1590/1809-4430eng.agric.v36n6p1063-1072/2016

Pavinato, P. S., Merlin, A., \& Rosolem, C. A. (2009). Phosphorus fractions in Brazilian Cerrado soils as affected by tillage. Soil and Tillage Research, 105(1), 149-155. https://doi.org/10.1016/j.still.2009.07.001

Peluco, R. G., Marques Júnior, J., Siqueira, D. S., Pereira, G. T., Barbosa, R. S., \& Teixeira, D. D. B. (2015). Mapeamento do fósforo adsorvido por meio da cor e da suscetibilidade magnética do solo. Pesquisa Agropecuária Brasileira, 50(3), 259-266. https://doi.org/10.1590/S0100-204X2015000300010 
Pinto, F. A., Souza, E. D. D., Paulino, H. B., Curi, N., \& Carneiro, M. A. C. (2013). P-sorption and desorption in savanna Brazilian soils as a support for phosphorus fertilizer management. Ciência e Agrotecnologia, 37(6), 521-530. https://doi.org/10.1590/S1413-70542013000600005

Rolim Neto, F. C., Schaefer, C. E. G. R., Costa, L. M., Corrêa, M. M., Fernandes Filho, E. I., \& Ibraimo, M. M. (2004). Adsorção de fósforo, superfície específica e atributos mineralógicos em solos desenvolvidos de rochas vulcânicas do Alto Paranaíba-MG. Revista Brasileira de Ciência do Solo, 28(6), 953-964. https://doi.org/10.1590/S0100-06832004000600003

Roy, E. D., Willig, E., Richards, P. D., Martinelli, L. A., Vazquez, F. F., Pegorini, L., ... Porder, S. (2017). Soil phosphorus sorption capacity after three decades of intensive fertilization in Mato Grosso, Brazil. Agriculture, Ecosystems \& Environment, 249, 206-214. https://doi.org/10.1016/j.agee.2017.08.004

Santos, F. G., Novais, R. F., Neves, J. C. L., Foloni, J. M., Albuquerque Filho, M. R., \& Ker, J. C. (2008). Produtividade e aspectos nutricionais de plantas de soja cultivadas em solos de cerrado com diferentes texturas. Revista Brasileira de Ciência do Solo, 32(5), 2015-2025. https://doi.org/10.1590/S0100-0683 2008000500023

Santos, H. C., Oliveira, F. H. T., Salcedo, I. H., Souza, A. P., \& Silva, V. D. M. (2011). Kinetics of phosphorus sorption in soils in the state of Paraíba. Revista Brasileira de Ciência do Solo, 35(4), 1301-1310. https://doi.org/10.1590/S0100-06832011000400024

Schoonheydt, R. A., \& Johnston, C. T. (2011). The surface properties of clay minerals. EMU Notes in Mineralogy, 11, 337-373. https://doi.org/10.1180/EMU-notes.11.10

Schulze, D. G. (1984). The influence of aluminum on iron oxides. VIII. Unit-cell dimensions of Al-substituted goethites and estimation of $\mathrm{Al}$ from them. Clays and Clay Minerals, 32(1), 36-44. https://doi.org/10.1346/ CCMN.1984.0320105

Schulze, D. G., \& Schwertmann, U. (1984). The influence of aluminium on iron oxides: X. Properties of Al-substituted goethites. Clay Minerals, 19, 521-539. https://doi.org/10.1180/claymin.1984.019.4.02

Schwertmann, U., \& Kämpf, N. (1985). Properties of goethite and hematite in kaolinitic soils of Southern and Central Brazil. Soil Science, 139(4), 344-350. https://doi.org/10.1097/00010694-198504000-00008

Schwertmann, U., \& Taylor, R. M. (1989). Iron oxides. In J. B. Dixon, \& S. B. Weed (Eds.), Minerals in soil environments (2nd ed., pp. 379-438). Madison: Soil Science Society of America.

Simões Neto, D. E., Oliveira, A. C., Freire, F. J., Freire, M. B. G., Oliveira, E. C. A., \& Rocha, A. T. (2009). Extração de fósforo em solos cultivados com cana-de-açúcar e suas relações com a capacidade tampão. Revista Brasileira de Engenharia Agrícola e Ambiental, 13(6), 840-848. https://doi.org/10.1590/ S1415-43662009000700005

Simões Neto, D. E., Oliveira, A. C., Freire, F. J., Freire, M. B. G., Oliveira, E. C. A., \& Rocha, A. T. (2015). Adubação fosfatada para cana-de-açúcar em solos representativos para o cultivo da espécie no Nordeste brasileiro. Pesquisa Agropecuária Brasileira, 50(1), 73-81. https://doi.org/10.1590/s0100-204x2015000 100008

Soares, M. M., Sediyama, T., Neves, J. C. L., Júnior, S., \& Silva, L. J. D. (2016). Nodulation, growth and soybean yield in response to seed coating and split application of phosphorus. Journal of Seed Science, 38(1), 30-40. https://doi.org/10.1590/2317-1545v38n1155355

Sousa, D. M. G., \& Lobato, E. (2002). Calagem e adubação para culturas anuais e semiperenes. In D. M. G. Sousa, \& E. Lobato (Eds.), Cerrado: Correção do solo e adubação (pp. 283-315). Planaltina: Embrapa Cerrados.

Valadão Júnior, D., Bergamin, A. C., Reis Venturoso, L. D., Schlindwein, J. A., \& Otomar Caron, B. (2008). Adubação fosfatada na cultura da soja em Rondônia. Scientia Agraria, 9(3), 369-375. https://doi.org/ 10.5380/rsa.v9i3.11537

Vieira, R. C. B., Fontoura, S. M. V., Bayer, C., Moraes, R. P. D., \& Carniel, E. (2015). Phosphorus fertilization for high yield of soybean, maize, and winter cereal crops in rotation in oxisols under long-term no-till in the South Central region of Parana, Brazil. Revista Brasileira de Ciência do Solo, 39(3), 794-808. https://doi.org/10.1590/01000683rbcs20140463 
Yang, F., Xu, X., Wang, W., Ma, J., Wei, D., \& He, P. (2017). Estimating nutrient uptake requirements for soybean using QUEFTS model in China. PLoS ONE, 12(5), e0177509. https://doi.org/10.1371/journal. pone.0177509

Withers, P. J., Rodrigues, M., Soltangheisi, A., Carvalho, T. S., Guilherme, L. R., Benites, V. D. M., ... Andreote, F. D. (2018). Transitions to sustainable management of phosphorus in Brazilian agriculture. Scientific Reports, 8(1), 2537. https://doi.org/10.1038/s41598-018-20887-z

Zhang, D., Liu, C., Cheng, H., Kan, G., Cui, S., Meng, Q., ... Yu, D. (2010). Quantitative trait loci associated with soybean tolerance to low phosphorus stress based on flower and pod abscission. Plant Breeding, 129(3), 243-249. https://doi.org/10.1111/j.1439-0523.2009.01682.x

\section{Abbreviations}

PAC: maximum phosphorus adsorption capacity; RYL: Red-yellow Latosol; TH: Typic Hapludalf; Pavail: available phosphorus; P: phosphorus; RDM: Root Dry Mass; ADM: Aerial Dry Mass; TDM: Total Dry Mass; PH: Plant Height; RV: Root Volume; PP: Pods per Plant.

\section{Copyrights}

Copyright for this article is retained by the author(s), with first publication rights granted to the journal.

This is an open-access article distributed under the terms and conditions of the Creative Commons Attribution license (http://creativecommons.org/licenses/by/4.0/). 